\title{
The Dynamics And Vicissitudes of China- India Relations in The Post-2017 Border Conflict
}

\author{
Ngboawaji Daniel Nte \& Oluka Nduka Lucas \\ Novena University \\ Awajiowa Daniel Nte \\ Global Intelligence, Peace and Security Institute
}

Awwal Isah

Nigerian Defence Academy

\begin{abstract}
This study argued that one of the primary reasons China-India renewed diplomatic intercourse after the border conflict of 2017 was the fear of emergent cross-border terrorism in the Southern Asia region. It also argued that, although both nations have different approaches to terrorism, there was a need for a collective fight against the emerging cross-border terrorist groups believed to have been strengthened by ISIS affiliation. Furthermore, the study revealed that India and China's rising economic posture contributed to the renewed diplomatic ties. On these premises, this study is posed to examine the reasons and benefits of China-India's renewed economic, diplomatic intercourse after the border conflict of 2017.
\end{abstract}

Keywords: China-India, Economic Relations, Diplomatic Relations, Crossborder terrorism

Tulisan ini berargumen bahwa salah satu alasan utama China-India memperbarui hubungan diplomatik setelah konflik perbatasan tahun 2017 adalah karena ketakutan akan terorisme lintas batas yang muncul di kawasan Asia Selatan. Tulisan ini juga berpendapat bahwa, meskipun kedua negara memiliki pendekatan berbeda terhadap terorisme, ada kebutuhan untuk perjuangan kolektif melawan kelompok teroris lintas batas yang diyakini telah diperkuat oleh afiliasi ISIS. Lebih lanjut, tulisan ini mengungkapkan bahwa postur ekonomi India dan China yang sedang rising berkontribusi terhadap hubungan diplomatik kedua negara paska konflik perbatasan 2017. Berdasarkan premis-premis tersebut, penelitian ini diajukan untuk mengkaji alasan dan manfaat hubungan ekonomi dan diplomatik China-India yang diperbarui setelah konflik perbatasan tahun 2017.

Kata-kata Kunci: China, India, Hubungan Ekonomi, Hubungan Diplomatik, Terorisme lintas batas 
In recent years, the Sino-Indo diplomatic relations have increased significantly because of their diplomatic strategies. On the political front, both countries have strengthened their interactions in distinct manners that have dramatically improved their relations and helped build confidence and trust between them. As rising global powers, fastest-growing economies, and developed giant economies among the Third World Countries (TWCs) to which they belong, China and India are indisputably contributing to bilateral and multilateral cooperation with the rest of the world in recent times. Zhang Li (2010:2) argued that both countries have, over the years, developed vibrant economic and trade relations or links through a multilateral and bilateral partnership with other countries. From this premise, it can be argued that China's growing political, military, and economic momentum after the industrial revolution and its relevance in regional politics asserted to cement its relations with India after the border dispute of 2017.

It is important to note that China and India share common elements: geographically, both countries share the same continent and are separated by a common border. Demographically, they are the giant economies of the continent with populations exceeding one billion. Historically, both countries have a rich and long development history that made them prominent in contemporary history. Regarding economic development, they share similarities and differences occasioned by their political differences and in which democracy is well-rooted in India. At the same time, state power within the People's Republic of China is exercised through the communist party, the Central People's Government (State Council). Therefore, it is believed that China's political framework lies within socialist democracy because the Communist party is a central authority that acts in the people's interest (Marelli \& Signorelli 2011; Alan 2018).

Albina (2018:5) argued that the perceived relationship between the two Asia dragon and elephant are not always as good as they could have been right from the 01 January 1950 establishment of diplomatic relations between Beijing and New Delhi. He opines that the challenges to the China-India initial cooperation were because of the emergent Sino-Indo border dispute, which originates from British and Russian expansionism policies in which Tibet was 
Ngboawaji Daniel Nte, Oluka Nduka Lucas, Awajiowa Daniel Nte, \& Awwal Isah

divided into a buffer zone. Furthermore, he argued that despite the changed bilateral relations towards pragmatic cooperation, both countries still feel the consequences of the war in terms of a trust deficit and development of mutual relations. Further consequence lies in the degenerate border dispute that eventually led to a war in 1962 and a prolonged period of hostility and disrupted diplomatic intercourse between Beijing and New Delhi.

Sun (2020) argued that the year 2020 marks the $70^{\text {th }}$ anniversary of the establishment of diplomatic intercourse between Beijing and New Delhi, yet, since both countries established diplomatic ties, their relationship has always been shrouded with many issues that have created lots of concerns and worries to both countries on the one hand, and the regional and international communities on the other hand. These issues include the border war in 1962, the Sikkim skirmishes in 1967, the Sumdorong Chu Valley skirmish in 1987, and the most recent Doklam standoff in 2017. Also of note are the continuous disagreements over their shared border, the Dalai Lama issues, and China's security cooperation with Pakistan, trade, and the geopolitics of South Asia and the whole of Asia continent. Although, since April 2018 renewed bilateral economic relations between the two countries, China's policy toward India has shifted tremendously to that of mutual understanding and closer ties beneficial to both countries (Sun 2020).

The general objective of this study is to juxtapose and extrapolate the reasons behind the perceived border issue/conflict of 2017. The latest changing pattern of the more accepted bilateral economic relationship between China and India initiated in April 2018, and the need for sustenance. In addition, a brief historical origin of both countries is also significant since both have divergent and convergent economic developments in the past and the present, respectively.

This paper tries to address several questions: First, Why did China-India renew bilateral diplomatic relations after the border conflict of 2017? Second, what are the challenges posed by Chinese global influence and India's potential response? Third, what are the benefits of the 2018 economic convergence to both countries and the rest of the world? Finally, what are the best strategies to sustain the renewed bilateral economic relations between the two 
The Dynamics And Vicissitudes of China-India Relations in

The Post-2017 Border Conflict

countries?

The study adopted a historical design which is qualitative. A qualitative case study lends itself to an explorative, descriptive, and explanatory method. Hence its adoption to examine why Beijing and New Delhi had to strengthen their economic relations again after the border issue of 2017. However, this implies that the study relied on a secondary source of data. A secondary data source refers to materials not originally from the researcher, but existing literature and those gathered from textbooks, journals, official documents, and internet materials.

\section{Shifting Perceptions and Balance of Power in the Sino- Indo Relations}

Since 2018 there has been a change of circumstances and attitudes toward each other. The growing bilateral trade and commerce, thus, are the basis for Sino-India's exclusion of military aggressions in their relations in recent years. Some of the contributing factors are geographical scenario, Soviet Union disintegration, and a new economic order (Albina 2018:5). In June 2017, the headlines of newspapers discussed the new manifestation of the old border issue between China and India. China and India were acting like a patron of the other countries in the territory.

The conflict at the Sino-Indo border began with the Chinese attempt to construct a new road in the Doklam area. However, Bhutan, a country in South Asia, claims that Doklam is the territory of Bhutan, and India sees herself as a historical defender of Bhutan and sent troops to the Doklam area to prevent the construction. On the other hand, China sees the Doklam area as a natural continuation of Tibet, an autonomous region of China. Therefore, while India sees the construction as a violation of Bhutan's border, China, on the other hand, sees the issue as a legitimate pursuit of her territorial interest (Jacob 2017).

Surprisingly, as international and regional allies of both nations of China and India, as well as national dailies or newspapers, talked about the rising tension and probability of war between the two 
Ngboawaji Daniel Nte, Oluka Nduka Lucas, Awajiowa Daniel Nte, \& Awwal Isah

nations, in April 2018, both countries decided to bond with each other for economic benefit through renewed bilateral relations and subsequently initiated a set of new economic agreements (Ivanovitch 2018). Pathak (2018) argued that the emergence of terrorism in the Southern Asia region and China and India contributed to the urgent need for regional and international cooperation to address this evil. To Pathak, this was one of the reasons for the renewed diplomatic relation between the two nations. She further argued that China, which has emerged as an integral part of the international system because of its diplomatic and economic maneuvers, has its shares of woes emanating from internal conflicts and insurgent terrorist groups. Like China, since its independence in 1947, India has had its shares of internal problems emanating from attacks from terrorist groups, ranging from ethno-nationalist terrorism to left-wing terrorism to religious terrorism and narco-terrorism.

Both countries' struggle with internal affairs was one reason for the renewed diplomatic intercourse between the two nations after the border issue of 2017 (Pathak 2018). However, the questions that emanated from the reversed perceived aggression between the two nations take pre-eminence in this study: from the reasons for the perceived aggression to the benefits of the renewed bilateral diplomatic intercourse in recent years. Scholars have been asking important questions about what changed in less than a year and why both nation-states try to build a peaceful relationship? Therefore, these questions are supposed to fill the gap in the international relations literature through the study on recent development between New Delhi (India) and Beijing (China). Essentially, this study aims to explain the developing economic convergence between China and India after April 2018.

Following the renewed diplomatic intercourse in Sino-Indo relations, pertinent questions relating to whether these newly found relations can be sustained in the forthcoming years considering the level at which both nations in the past struggle and compete to sustain their hegemony and influence in the region arises. Considering China's sustained construction of the road in the disputed territory of Bhutan, not far from strategically or critical section of the China-India border, one should not forget quickly 
the fact that the ongoing competition or rivalries of influence in the Southern Asia region are likely to resurface between the two growing super economies in the region. According to Lidarev (2018:2), the superiority and suspicion between Beijing (China) and New Delhi (India) led to India's boycott of the May 2017 Belt and Road Initiative (BRI) Summit held in Beijing in which China's adversaries, Japan and the United States also attended. It was alleged that India's boycott of the summit was because of the China-Pakistan economic corridor coupled with the sustained project in Pakistan-held Kashmir, which India saw as legitimizing Pakistan's position on the issue of Beijing. This behavior no doubt signifies New Delhi's profound uneasiness with the BRI, a project it regarded to have extended Beijing's power across the Southern Asia region.

If not properly managed, a possible resurface or repeat of this superiority problem will likely bedevil this new marriage between the two nations. China, which is regarded today as a more economically stable and more robust nation among the comity of nations in this era of globalization or industrialized economic regime more often than India, is likely to retain this apparent position in its relations with India and other nations in the region (Lidarev 2018). The consequence of this is a renewed rivalry between Beijing and New Delhi since the latter is likely to resist another Beijing's dominance in the region. In a nutshell, India's desire to protect what it sees as its sphere of interest in the region has to be considered. Tentatively, this issue is likely to bedevil China-India newly found relationship and create another dilemma if not properly harmonized. However, for this new marriage called renewed diplomacy to succeed, Beijing and New Delhi must be consistent and respect the April 2018 bond.

It should be recalled that one of the problems, although not apparent but quietly damaged Beijing and New Delhi relationship in 2017 before the renewed economic relations that started in 2018 was New Delhi's decision of November to join the revived Quadrilateral security dialogue (Quad), a strategic dialogue between the United States, Japan, India and Australia with a naval component (Vasudeva, 2018:4). On the contrary, Beijing was said to have opposed the Quad security dialogue, whom it alleged 
Ngboawaji Daniel Nte, Oluka Nduka Lucas, Awajiowa Daniel Nte, \& Awwal Isah

as a target against its interests and an anti-Chinese alliance of democracies aimed at containing and checking its maritime rise in the Indo-Pacific relations. In other words, it was believed that India's decision to join the Quad reflected its worries over China's growing power and assertiveness in the Indian Ocean on the one hand and India's readiness to hedge against China on the other hand (Vasudeva 2018). On the other hand, sun (2020) argued that despite the high-profile visits by senior Indian government officials to China, Beijing remains reconditely suspicious of New Delhi's strategic intention and ambition toward Beijing. This behavior, indisputably, is likely to create a sustained suspicion and distrust and impede their relationship in the future with profound implications if not divorce from Beijing's thought. Tentatively, the trade imbalance in favor of China, market access issues, and security threats across the South Asia region are likely to keep the bilateral trade relations between China and India limited if not adequately managed (Arora \& Saxena 2018).

The pertinent question is whether these initial rivalries or issues between Beijing and New Delhi are wholly resolved and cemented now and before their marriage called economic diplomacy? Are there no possibilities that these issues are likely to resurface in the future as both nations continue to protect their respective interests in the Southern Asia region? Tentatively, these pertinent questions or issues are best reconciled through a detailed chronology of the historical foundation of the Sino-India relationship before and after the 2017 border conflict. The reason behind the renewed diplomatic intercourse cum the benefits of this renewed relationship. Therefore, this study examines the changing motives in the Sino-Indo relations, often regarded as Beijing (China) and New Delhi (India) diplomatic relations.

This study adopted the Balance of power theory, which is as old as international politics itself and whose origin is traced to Europe's counter-reaction to the near-complete domination of Europe by Napoleon of France. It was argued that in September 1814, the then great powers of Europe, Russia, Prussia, Austria, France, and Great Britain, in a Congress or Convention held in Vienna, met purposely to redraw the map of Europe after the defeat of Napoleon aggression in Europe. To accomplish this 
goal, Austrian Foreign Minister Prince Klemens Von Metternich and British Foreign Secretary Viscount Castlereagh developed the theory of Balance of power (Sparknotes 2020). It was also noted that one of the most influential proponents of Balance of power politics in the Eighteenth century was the Scottish philosopher, David Hume, who wrote extensively on international politics in his History of England: From the Invasion of Julius Caesar to the revolution in 1688 (1754), and Essay of the Balance of Trade and Balance of Power (1752). The theory had gained prominence in international politics after the First and Second World Wars when it became necessary for the World powers to balance the powers of recalcitrant nation-states and the power of emergent tyrants in the international system.

Its emphasis is on equal distribution of power to avoid domination of the polity by one or single power. It is a core concept in the study of international politics and a central concept in diplomatic practice since its primary focus is understanding interstate relations. Chand (2020) sees Balance of power as a means to seek a state's security through an internal build-up of power or by allying with other states to prevent one state from accumulating too much power that could be detrimental to the international community future. Because within international system, concentration of power in one powerful state needs to be checked and balanced by the collective power of other states (Schweller 2016). As a nation's power grows to a point, it menaces other powerful states, counterbalancing coalition emerges to restrain the rising power, such that any bid for world hegemony results in self-defeat, as evident in the defeat of Nazi Germany uprising, which gave birth to the Second World War (WWII). This context is also a clear example of the Sino-Indo conflict and the reason for the renewed diplomatic intercourse between the two Asia rising giant powers in recent times.

Balance of power is a principle or a method adopted by the nationstates of the international system to check the emergence of preponderant power or powers in the international system. The essence of this is to ensure that the preponderant power does not emerge to dominate the prevailing international system. Therefore, its central tenet ensures equilibrium of position or 
Ngboawaji Daniel Nte, Oluka Nduka Lucas, Awajiowa Daniel Nte, \& Awwal Isah

parity between the strongest and weakest nation-states in the international system. The central assumption of the theory is: if none of the states or group of states are allowed to grow too powerful above the others, there could be peace in the system; and wherever notion-state or group of states suddenly become more powerful than others, those threatened should team up to defeat the aggressor state and restore international peace, among others (Oromaregheke \& Oluka 2016:68).

Therefore, the theory depicts the actual situation in the Sino-Indo degenerate border dispute that eventually led to the 1962 war and a prolonged period of hostility, distrust, and disrupted diplomatic intercourse, as well as the renewed border issue of 2017. This depiction derived from both country excessive power assertion in the Southern Asia region, thereby disrupting the region's peace. This attracted world powers, particularly the United States or Washington's deliberate attempt to balance Beijing's overbearing influence, interest, and hegemonic tendency in the South Asia region and the international arena. It can be argued that the need to balance the powers asserted by China and India led to the recent economic, diplomatic relations between the two nation-states and the rest of the world. This premise reflects what it takes to balance the power of states in the international system.

\section{Fundamental Reasons for the China-India Renewed Bilateral Diplomatic Relations after 2017 Border Conflict}

It is important to note that China and India have unique historical ties, which most scholars perceived as the origin of their modern diplomatic intercourse. After about 200 years under British colonial rule, India declared its independence from England in 1947. On the other hand, China which had an almost 30 years long war period, embraced the Communist revolution in 1949. In the line of this history, both countries attached importance to their cordial relationship throughout the 50s. It was argued that India was one of the first non-communist countries to recognize communist China and support China in the international political arena. It was further noted that both countries shared joint 
opposition against colonialism and imperialism during these years, which further strengthened their relationship (Arif 2013; Sun 2020:2).

Sun (2020) argued that the reason Beijing shifted its policy toward New Delhi and why it actively promoted closer ties with New Delhi since 2018 was because of the drastic rupture from the Doklam standoff between the two countries in 2017, coupled with Beijing's fear of the emerging New Delhi (India)-Washington (US) alliance which was part of Washington's Indo-Pacific strategy. Also significant is that India sees China as its primary threat, while China, on the other hand, sees India and South Asia as secondary threats or challenges. Thus, it referred to reduced cost and minimized military and strategic resources on India to concentrate on its more significant challenges or threats from the West, especially the United States.

Suffice, therefore, to chronologically provide a brief analysis of the genesis of the crossroads in Sino-Indo diplomatic relations. First, it should be recalled that Doklam is an area in dispute, specifically between China and Bhutan, which is located between their trijunction with India. According to Barry et al. (2017), unlike China and Bhutan, India did not claim the ownership of Doklam but supported Bhutan's claim. China's claim on Doklam was based on the 1890 Convention of Calcutta between China and Britain, which was stated in Article 1 of the Charter. Based on the provision of this Convention, China asserts that the starting point of the SikkimTibet border is Mount Gipmochi which is on the Bhutan frontier and which clearly defines the tri-junction point. Therefore, based on Chinese claims, Doklam is located in the Xigaze area of Tibet, bordering the state of Sikkim, although Bhutan was not a party to the Convention (China Foreign Ministry 2017).

In 1949, Bhutan signed a treaty with India that allowed India to guide its diplomatic and defense affairs. In 2007, the treaty was superseded by a new Friendly Treaty that replaced the provision that made it mandatory for Bhutan to take India's guidance on foreign policy and provided broader sovereignty. In a nutshell, the 2017 China-India conflict predates these historical events. Scholars have argued that the 2017 China and India standoff and what is today known as the military border standoff between the 
Ngboawaji Daniel Nte, Oluka Nduka Lucas, Awajiowa Daniel Nte, \& Awwal Isah

India Armed Forces and the People's Liberation Army of China over Chinese construction of a road in Doklam near a tri-junction border area, known as Donglang or Donglang Caochang (meaning Donglang pasture or grazing field) in Chinese. On 16 June 2017, Chinese troops with construction vehicles and road-building equipment began to extend an existing road southward in Doklam, a territory claimed by both China and India's ally Bhutan. On 18 June 2017, as part of what was known as Operation Juniper, about 270 Indian troops armed with weapons and two bulldozers crossed the Sikkim border into Doklam to stop the Chinese troops from constructing the road. On 28 August the same year, both India and China announced that they had withdrawn all their troops from the face-off site in Doklam. According to Barot (2020), the recent stabilized and strengthened diplomatic relationship between Beijing and New Delhi after the border skirmishes at Doklam in 2017 was preceded by several mutual engagements and at various forums such as the Wuhan Summit, Mamallapuram summit, BRICS summit (Brazil, Russia, India, China, and South Africa, often known as the emerging economies), etc.

However, the newly found relationship was further cemented by bilateral diplomatic visits, military and economic agreements, and coincidentally border disputes that began to take place on the agenda of Sino-Indo relations. It was noted that the first significant conflict was about the position of Tibet in which China claimed that Tibet was in the territory of China. However, India accepted China's protector role on Tibet but claimed that Tibet should be autonomous. It was argued that the reason for conflict in 1959 to 1962 between India and China was because China decided to intervene in the Tibet dispute only after it reached its peak in 1959 on the one hand, and the other hand, revolt that had occurred in Tibet which led to the escape of Dalai Lama from Tibet to India. It was believed that after these events, both nations witnessed over 15 years long period of strained diplomatic relations, and as a consequence, in 1976, both countries withdrew their ambassador from each other's territories (Arif 2013).

It was noted that after 1976 the relationship between India and China began to normalize again with lots of international dialogues until both countries eventually cemented their diplomatic bond 
economically, politically, militarily, and technologically, although there were some obstacles. These obstacles include the conflict situation of Tibet, border dispute, ocean problem, and nuclear technology. Apart from the problem of Tibet's situation, the border problem is on the agenda of both countries in that they are opposed to each other about territorial rights. But, on the other hand, both countries have no choice but to compete with each other about coastal rights now that they share the same trade roads in the Indian Ocean. Lastly, developments in nuclear technology cause tension in Sino-Indo relations. This tension was seen in China's support to Pakistan about building a nuclear technology and India's nuclear test in 1998 (Arif 2013).

Extant literature revealed that the improvement of the SinoIndo relationship was because of the collapse and subsequent disintegration of the Soviet Union cum the event of 9/11 in the United States of America (USA). These events could be considered as a milestone for these countries' relationship during the period. These complex events strengthened the economic bonding process between India and China from 2017 to 2018. According to Keohane \& Nye (1987:731), complex interdependency is an ideal international system that bonds one society to another without hierarchy or dominant military force. It was argued in some quarters that complexity is the best relationship the two nationstates can have, whether they are of equal status in the international arena or not since the complexity is often reciprocal. However, the Sino-Indian relationship was a perfect example of complex interdependency, which prioritized their interdependence in the following areas: military agreements, economic engagement, behavior against terrorism, and border issue. Just as the other part of the world, the collapse of the Soviet Union also affected these two countries. During these years, while China was in the middle of her new economic regulations, India lost its ally with the collapse of the Soviet Union. This situation was complicated by the 1987 border dispute between India and China, which put the countries in a delicate position (Jacob 2013).

In 1993 India and China signed a peace and tranquility agreement that contains regulations about border control and military infrastructure. In the agreement, both countries determine a Line 
Ngboawaji Daniel Nte, Oluka Nduka Lucas, Awajiowa Daniel Nte, \& Awwal Isah

of Actual Control that contains some intervention rights procedures in the borderline. Along with this, composed of military personnel and diplomats, a Joint Working Group was also created to complete the agreement. Notably also was the declaration of these two countries that took place in 2003. Jacob (2013) argued that regulation between both countries also led to a joint declaration against terrorism and renewed economic relations. Furthermore, Jacob claims that the former agreements, particularly the military agreement, were critical for peace-building.

Gandhi (2014), on the other hand, argued that the complex interdependency of Sino-Indo relations was a bonding instrument between the two countries even before the border dispute in 2017. To him, the changing motive of the political behavior of both countries was shaped by the 2017 border issue, which has continued to strengthen the diplomatic relations between them. To him, another significant factor was the agenda of China's economic reform. This point of view was complemented by Brant (2018) when he argued that after the emergence of Xi Jinping as the president of China, he introduced the new economic reform plan in China, which was not meant to swerve from the communist administration but was to further open-up politics in China's economy. This momentum could be the reason for China's behavior alteration from 2017 to 2018.

Further, Ayres (2014) noted that another significant factor was the election of Narendra Modi as the Indian Prime Minister in 2014 and his re-shaping foreign policy, often known as the Modi Doctrine. This doctrine was meant to project Indian as a political power in the international arena with a pragmatic framework of bilateral trade agreements and creating peaceful relationships with her neighbors. The influence of the Modi doctrine could also be seen as a reason that changed India's behavior toward China from 2017 to 2018.

Keohane and Nye (1987) argued that the use of military power and the proliferation of nuclear weapons created some forms of burden to the economies of both states, and at the same time, increased threat to their diplomatic intercourse. However, these also created local resistance and opposition in the country and damaged their economic purposes. Therefore, both nation's behavior affected 
their expenditures, and at the same time, creating a burden on their economies. Goh (2018) has argued that despite the rivalry between India and China, China's largest export market was still in India. Unfortunately, China's export market was affected to a greater extent by the behaviors of both nations. Goh also argued that the fear of escalating nuclear technology was one of the causes of the Sino-Indian conflict, though this was one of the reasons that created fear of extreme force in the 2017 border dispute by both nations. Sundaram \& Marlow (2018) has argued that the effect of Trump's discourse also could be the cause of India's and China's behavior from the 2017 border dispute to 2018 economic developments. He argued further that the perception of threat from the international system prompted both India and China to preserve and strengthen their relationship instead of undermining it with border disputes. Scholars and state actors in the international system perceived this change of attitude or behavior as the strengthening of economic relations between the two states.

\section{Challenges posed by Chinese global influence and Indian Potential Response}

Undoubtedly, Beijing and New Delhi have faced critical strategic choices from the struggle for influence and dominance in their regional and international affairs. This struggle has been identified as a significant challenge between the two giant economies from the Third World Countries (TWCs) of Asia, Africa, and Latin America before and after their renewed economic, diplomatic ties after the 2017 border issue. Also identified as a challenge to India, in particular, is Chinese rapid economic growth which ordinarily would have afforded Beijing greater control over its external environment. Apart from this, New Delhi's concern in recent times is Beijing or China's aggressive behavior often exhibited in its relations with the region, particularly along the China Sea region and the other neighboring nations. Notably, Beijing's massive wealth and influence not only in the region but also across the global system and which it brings to bear on international politics (Rajagopalan 2017:1). Some scholars have argued that China's (Beijing) recent growth in virtually all sectors of the global 
Ngboawaji Daniel Nte, Oluka Nduka Lucas, Awajiowa Daniel Nte, \& Awwal Isah

economy, which it asserts in its economic realignment with its economic rivals, particularly India (New Delhi), is the reason for the renewed economic, diplomatic ties between the two nations.

Rajagopalan (2017) has argued that China's rising military technology and other vital developmental sectors and its use to assert its influence in the international environment or market contributed to its superiority and hegemonic postures in the region. Also, of great concern and perturbing to New Delhi is Beijing's military superiority in the region, which it perceives as a significant threat to its existence. India, thus, has never been comfortable with Chinese hegemony in the region, the consequence of which it perceives as the reason for the rising threat in their regional relations. Another significant issue in the Sino-India relations is Beijing's increasing influence and popularity amongst members of the United Nations (UN) and in the Asia Infrastructure Investment Bank, which New Delhi alleged to have aided Beijing impetus to sabotage its interests and goals in their global affairs and Balance of power in the region.

It was argued that Beijing's (China) alignment with Pakistan, which New Delhi has not been comfortable with, is also a significant challenge to Beijing and New Delhi's diplomatic intercourse over the years. In a nutshell, Beijing's perceived overbearing influence and dominance across the Southern Asian region for decades has never been accepted by its rival Asia giant, New Delhi-India. The consequences of Beijing hegemonic posture in the South Asia region are a potential policy retaliation by its rival, New Delhi, which is likely to disrupt the renewed diplomatic intercourse between the two giant economies in the region and two of the fastest-growing economies in the global system and from the TWCs. Sun (2020) argued that one major challenge confronting China is achieving and managing its strategic goal: to stabilize its relations with India to avoid a two-front war with the USA and India.

A closer look at the Sino-India relations, thus, revealed that there is a possible obstruction in the future because of the fear of a persistent overbearing influence and regional dominance often exhibited by Beijing. Extant literature revealed that New Delhi's persistent quest for Balance of power between itself and Beijing would likely obstruct their future relations. Rajagopalan 
(2017) argued that India's potential policy response and strategy of nonalignment or alignment with China might not serve India's desired interests because of the overbearing influence, power politics, and geographical proximity that are already represented in their relations. This relationship was complicated by India's alignment with the United States, which China perceives as a plot to balance the same policy part already undertaken by China. Furthermore, there is the suspicion that the alignment between New Delhi and Washington, DC is a deliberate attempt to balance Beijing's interests in the region and the international environment. New Delhi's other strategic options, such as its effort to build indigenous military power and regional partnership, were necessary to counter Beijing's overbearing influence and hegemony in the South Asia region. Suffice, therefore, to state that New Delhi's policy strategies towards her suppose rival nation and now an ally are likely to balance India-China regional influence and power sufficiently and at the exact time cause another friction in the current diplomatic relation.

\section{Benefits of the China-India 2018 Economic Convergence}

The benefits of renewed diplomatic intercourse after a prolonged border dispute and cemented by the April 2018 renewed bilateral economic relationship cannot be overemphasized. It is important to note that the world economy has evolved since China emerged as one the largest economies in the world alongside the super economies from Europe and the United States. On the other hand, India's economy has also emerged to contend with that of China, Europe, and the United States in recent years. However, it is imperative to note that China and India have come to occupy the top slots in the emerging world economic order. Scholars and observers of this development argued that the rates at which the Sino-Indo economies are growing in recent years, both economies are likely to alter the world economic scenario. A report by Professor T. N. Srinivasan states that India stands at the fourth position after the US and China, and just a few steps below Japan in terms of national income, especially at the purchasing power parity exchange rates (Fernandes \& Ignatius 2006). 
Ngboawaji Daniel Nte, Oluka Nduka Lucas, Awajiowa Daniel Nte, \& Awwal Isah

The amazing fact about the economic growths of both China and India is the consistency and continued shift in the economic structures of both countries in the agricultural, oil and gas, textile, pharmacy, technical services, and industrial sectors of the world economy. Suffice, therefore, to state that India's economic power in recent times, like China's, has become increasingly involved in global economic policies and projects, especially in its contributions to infrastructural development to the rest of the world and in the TWCs precisely. For instance, China's Belt and Road Initiative (BRI) is a grand strategy by China to finance infrastructural developments in Asia, Europe, Africa, and beyond. The significance of this development lies in the fact that Beijing is now an important actor in global development. Its laissezfaire policy or free-market reform since 1979 contributed to its emergence as the fastest economies alongside the United States and the countries of Europe. Its annual gross domestic product (GDP) growth averaging 9.5\% through 2018 made the World Bank describe the country as the fastest growing economy globally (Fernandes \& Ignatius, 2006; CRS Report 2019). Domestically, both countries have been involved in mutual trade relations that are beneficial to both countries. For instance, in 2016, India's top exports to China included diamonds, cotton yarn, copper, and organic chemicals, while that of China to India included electrical machinery and equipment, fertilizers, antibiotics, and organic chemicals. These mutual benefits also extended to banking services; for instance, seven Indian Banks have branches or representative offices in China, and China, on the other hand, has one branch in India in Mumbai (Vasudeva 2018).

Marelli and Signorelli (2011) argued that China and India's super economic growths greatly influence the economies of the rest of the world economies, not only in good times but also in bad times. Both Asian countries are helping the world pull out of recession through their imports, despite persisting imbalances in specific trade relations, especially between China and the United States. Moreover, China and India's technical exports and sophisticated products reached far beyond Asia to the rest of the world, including the United States. 
The Dynamics And Vicissitudes of China-India Relations in

The Post-2017 Border Conflict

\section{Conclusion}

In this study, we examined the changing motives of the IndiaChina relationship between 2017 and 2018. First, we revealed how complex the interdependence between Beijing and New Delhi was before the border dispute in 2017. Secondly, we explained the learning process of these two countries along with a historical process that existed before the 2018 economic convergence. Subsequently, the factors likely to resurrect the initial differences between the two economic giants were clearly illustrated and fervently discussed. Finally, the perceived factors that may affect this relationship, Xi Jinping's economic reform plan, and Modi Doctrine, were briefly mentioned.

Subsequently, the study revealed that both nuclear technology tensions and probable trade loss could cause behavior alteration from 2017 to 2018. How India and China locate each other was prioritized to understand the study's central tenet, which is the renewed economic, diplomatic tie between the two giant economies in the region. In other words, the study has answered how both India and China perceived the international system and relate with the same now that they have renewed their diplomatic relations after the border issue of 2017. However, the fact remains that the recent relationship between Beijing and New Delhi could only be sustained if both nations continue to respect their policy divergences and similarities and pursue the same or similar agenda at the regional and international fronts.

Sudden alteration in the Sino-India relations may not be necessary for their new marriage to succeed and for economic drives to be jointly strengthened. At a point, we reiterated that the 2017 stressful relationship between Beijing and New Delhi, among several other reasons, was the main reason for the newly found legacy of 2018. The implication is that both Beijing and New Delhi must continue to rethink the initial deteriorating relationship and work hard to sustain peaceful coexistence without a repeat of the conflict before them. On a general note, it is evident that many factors were responsible for the shift from border issues to the renewed economic realignment. To secure peaceful coexistence and a favorable atmosphere for economic integrations and investments across the region, Beijing and New Delhi had no options but to 
Ngboawaji Daniel Nte, Oluka Nduka Lucas, Awajiowa Daniel Nte, \& Awwal Isah

change their hostility towards each other, vastly reducing the military conflict along their border. Most importantly, the change of attitude towards each other has increased trust in their renewed diplomatic relation.

\section{References}

\section{Books and Chapter in Books}

Oromaregheke, B \& N. L. Oluka, 2016. Theory of International Relations. Benin City: Allen Publications.

\section{Journal}

Albina, M., 2018. "The Sino-India border issue is a factor for the development of bilateral relations", SAGE Asia Journal of Comparative Politics, 3(1):3-12.

Arif, S. M., 2013. "A History of Sino-Indian Relations: From Conflict to Cooperation", Academic research journals, 1(4):129-137.

Barot, Y., 2020. "India-China relations-the present, the challenges and the future", The Round Table, 109(1):92-93.

Jacob, J.T., 2013. "Bilateral Agreements and Sino-Indian Confidence-Building Measures", Institute of Peace and Conflict Studies: 151-161.

Jacob, J. T., 2017. "Explaining the India-China Standoff at Doklam: Causes and Implications", Aakrosh, 20(77):60-76.

Keohane, R. O., \& J. S. Nye., 1987. "Power and interdependence revisited", International Organization, 41(04):725.

Li, Z., 2010. "China-India Relations Strategic Engagement and Challenges”, Asie Visions, 34.

Marelli, E. \& M. Signorelli, 2011. "China and India: Openness, Trade and Effects in Economic Growth", The European Journal of Comparative Economics, 8(1):129-154. 
The Dynamics And Vicissitudes of China-India Relations in The Post-2017 Border Conflict

Pathak, S., 2018. "India-China Economic Relations and the Persistent Trade Deficit”, India Foundation Journal, March-April 2018.

\section{Online Article}

Alan, W., 2018. "Is China a democracy? A long and better answer", Inkstone, 10 September [online]. In https://www. inkstonenews.com/china-translated/china-democracy/ article/2163522 [accessed 10 June 2020].

Arora, K. \& R. Saxena, 2018. "India-China Economic Relations: An Assessment", South Asian Voices, 21 April [online]. In https://southasianvoices.org/india-china-economicrelations-an-assessment/ [accessed 14 May 2020].

Ayres, A., 2014. "The Modi Doctrine", Outlook India, 10 June [online]. In https://www.outlookindia.com/website/ story/the-modi-doctrine/291047 [accessed 10 June 2020].

Barry, E., et.al., 2017. "How India and China have come to the brink over a remote Mountain pass", The New York Times, 26 July [online]. In https://www.nytimes.com/2017/07/26/ world/asia/dolam-plateau-china-india-bhutan.html [accessed 10 June 2020]

Brant, R. 2018." China President Xi's economic reform promises underwhelm", $B B C, 5$ November [online]. In https://www. bbc.com/news/business-46093484 [accessed 10 June 2020].

Chand, S. 2020. "The Concept of Balance of Power in Contemporary International Politics", Yourarticlelibrary, [online]. In www.yourarticlelibrary.com/politics/the-conceptof-balance-of-power-in-contemporary-internationalpolitics/5760 [accessed 14 May 2020].

China Foreign Ministry. 2017. "The facts and China's position concerning the India border troops' crossing of the ChinaIndia boundary in the Sikkim sector into Chinese territory", Xinhua, 3 August [online]. In https://www.chinadaily. com.cn/world/2017-08/03/content_30341027.htm [accessed 14 May 2020]. 
Ngboawaji Daniel Nte, Oluka Nduka Lucas, Awajiowa Daniel Nte, \& Awwal Isah

Congressional Research Service. 2019. "China's Economic Rise: History, Trend, Challenges, and Implications for the United States", 25 June [online] in https://www.everycrrsreport. com/ [accessed 14 May 2020].

Fernandes, P. \& G. Ignatius., 2006. "Role of Indian in the global economy", Economic Times, 28 October [online]. In https://m.economictimes.com/role-of-india-in-globaleconomy/articleshow/193898,cms [accessed 14 May 2020].

Gandhi, Vrushhabh, 2014. "Indo China Bilateral Trade Relations', [online]. In https://www.academia.edu/11386379/Indo_ China_Bilateral_Trade_Relations_Project_Report_ Subject_Code_606_A_project_by [accessed 14 May 2020].

Goh, M., 2018. "China and India will lead the world's nuclear power growth, experts say", $C N B C$, o8 November [online]. In https://www.cnbc.com/2018/11/o8/china-india-willlead-global-nuclear-power-production-growth-experts. html [accessed 14 May 2020].

Ivanovitch, M., 2018. "China and India are trying to write a new page of the world economy". CNBC, 29 April [online]. In https://www.cnbc.com/2018/04/29/china-india-tryingto-write-a-new-page-of-world-economy--commentary. html [accessed 14 May 2020].

Lidarev, I., 2018. "2017: A tough year for China-India relations", The Diplomat, 4 January [online]. In https://thediplomat. com/2018/01/2017-a-tough-year-for-china-indiarelations [accessed 14 May 2020].

Rajagopalan, R., 2017. "India's Strategic Choices: China and the Balance of Power in Asia", Carnegie India, 14 September, [online]. In https://carnegieindia.org/2017/09/14/indias-strategic-choices-china-and-balance-of-power-in-asiapub-73108 [accessed 14 May 2020].

Schweller, R.,2016. "The Balance of Power in World Politics", Oxford ResearchEncylopedias, 9May[online].Inhttps://oxfordre. com/view/10.1093/acrefore/9780190228637.001.0001/ acrefore-9780190228637-e-119 [accessed 14 May 2020]. 
The Dynamics And Vicissitudes of China-India Relations in The Post-2017 Border Conflict

Sparknotes, 2020. "The balance of Power in Europe (1871-1814) History", Sparknotes [online]. In https://www.sparknotes. com/history/european/1871-1914/section8/ [accessed 14 May 2020].

Sun. Y., 2020. "China's Strategic Assessment of India", War on the Rocks, 25 March [online]. In https://warontherocks. com/2020/03/chinas-strategic-assessment-of-india/ [accessed 14 May 2020].

Sundaram, K. \& I. Marlow, 2018. “Trump's Trade War Pushes China to Old Foe India", Bloomberg, 28 June [online]. In https://www.bloomberg.com/news/articles/2018-06-27/ trump-s-trade-war-pushes-china-closer-to-old-foe-india [accessed 14 may 2020].

Vasudeva, P.K., 2018. "2017: Was a tough year for China-India", Indian Defence Review, 13 January [online]. In http:// www.indiandefencereview.com/news/2017-was-a-toughyear-for-china-india-relations/ [accessed 14 May 2020]. 